\title{
Adopsi Inovasi Layanan Antar Jemput Ijin Bermotor Pelayanan Terpadu Satu Pintu Provinsi DKI Jakarta
}

\author{
${ }^{1}$ Dani Setiarini ${ }^{2}$ Achmad Lutfi \\ ${ }^{12}$ Program Studi Kebijakan Publik, Fakultas Ilmu Administrasi, Universitas Indonesia \\ Depok,Indonesia \\ Email : ${ }^{1}$ setiarinidani@gmail.com, ${ }^{2}$ achlutfi@yahoo.com \\ Received: 04 November 2019; Revised: 15 Februari 2020; Accepted: 17 Februari 2020
}

\begin{abstract}
The phenomenon of the emergence of various innovations in the public sector gives a new color in the implementation of public services. The presence of licensing pick-up service known as AJIB from the Jakarta Capital Investment and One Stop Integrated Service (DPMPTSP) is a breakthrough innovation as an effort to improve service quality. AJIB purpose is to make it easier for the public to cut time and costs in the licensing process, as well as to eliminate the practice of intermediaries / brokers. However, in practice, the level of public adoption of AJIB services is still low. This study aims to analyze the factors that influence the adoption of AJIB service innovations by the public. This research was conducted using a qualitative descriptive method using the theory of innovation adoption put forward by Jenifer Wisdom, et al (2013). The results of the study concluded that DPMPTSP organizational provide adequate support for this service, but there are several factors that still need to be corrected by the Jakarta Capital Investment and One Stop Integrated Service to increase the adoption of AJIB service innovations to the community, including improvements regulations that support the implementation of $A J I B$, increasing socialization about AJIB services to the public and improving online channels to access AJIB services.
\end{abstract}

Keyword : Adoption Innovation: Public Service; Pick Up Service

\begin{abstract}
Abstrak
Fenomena munculnya berbagai inovasi di sektor publik memberi warna baru dalam implementasi layanan publik. Kehadiran layanan penjemputan perizinan sepeda motor (AJIB) dari Dinas Penanaman Modal dan Pelayanan Terpadu Satu Pintu (DPMPTSP) Provinsi DKI Jakarta merupakan terobosan inovasi sebagai upaya untuk meningkatkan kualitas layanan, memudahkan masyarakat untuk memangkas waktu dan biaya dalam proses pengurusan perizinan, sekaligus untuk menghilangkan praktik perantara/calo perizinan. Akan tetapi, dalam pelaksanaannya, tingkat adopsi masyarakat terhadap layanan AJIB ini masih rendah. Penelitian ini bertujuan untuk menganalisis faktor-faktor yang mempengaruhi adopsi inovasi layanan AJIB oleh masyarakat. Penelitian ini dilakukan dengan menggunakan metode deskriptif kualitatif dengan menggunakan teori adopsi inovasi yang dikemukakan oleh Jenifer Wisdom, et al (2013). Hasil dari penelitian menyimpulkan bahwa dukungan organisasi DPMPTSP DKI Jakarta atas layanan ini sudah cukup baik, akan tetapi terdapat beberapa faktor yang masih harus diperbaiki oleh Dinas Penanaman Modal dan Pelayanan Terpadu Satu Pintu Provinsi DKI Jakarta guna meningkatkan adopsi inovasi layanan AJIB kepada masyarakat, antara lain perbaikan regulasi yang mendukung penyelenggaraan AJIB, peningkatan sosialisasi tentang layanan AJIB kepada publik serta perbaikan saluran online untuk mengakses layanan AJIB.
\end{abstract}

Kata Kunci : Adopsi inovasi; Pelayanan Publik; Layanan Antar Jemput

Link DOI : http://dx.doi.org/10.31314/pjia.8.2.136-144.2019 


\section{PENDAHULUAN}

Pelayanan publik merupakan tolok ukur kinerja pemerintahan yang paling nyata, karena masyarakat berperan langsung dalam memberikan penilaian atas kualitas pelayanan publik yang diterima. Pelayanan publik yang berkualitas dapat memperbaiki tingkat kepercayaan masyarakat terhadap pemerintah. Namun, mewujudkan pelayanan publik yang baik di Indonesia hingga saat ini masih menjadi tantangan besar, bahkan menjadi penghambat dalam meningkatkan daya saing di tataran global. Hal ini terlihat dari beberapa patologi pelayanan publik seperti: inefisiensi birokrasi pemerintahan, instabilitas pemerintahan, dan rendahnya kapasitas aparatur untuk berinovasi yang menjadi faktor-faktor utama permasalahan daya saing Indonesia. Berbagai problematika utama tersebut menjadikan daya saing Indonesia di tahun 2018 menempati peringkat ke 45, masih tertinggal dari negara-negara ASEAN lainnya seperti: Thailand yang berada di peringkat 38, Malaysia di peringkat 25, dan Singapura di peringkat 2. Data dari Global Competitiveness Report di tahun 2018 menunjukkan 16 faktor yang mempengaruhi daya saing Indonesia yang berimplikasi pada terhambatnya pelayanan publik terutama pada aktivitas bisnis. Diantara 16 faktor tersebut, 3 faktor utama yang mempengaruhi minat pelaku bisnis untuk berinvestasi di Indonesia yaitu korupsi (13,8\%), birokrasi pemerintah yang tidak efisien $(11,1 \%)$ serta sulitnya akses pembiayaan (9.2\%). Birokrasi pemerintah yang tidak efisien termasuk juga didalamnya berupa ketidakpastian pelayanan, baik dalam hal persyaratan, prosedur dengan birokrasi yang kompleks, waktu penyelesaian serta kejelasan biaya.

Pemecahan masalah pelayanan publik sudah tidak dapat lagi menggunakan cara cara yang biasa. Pemerintah dituntut cara cara yang biasa. Pemerintah dituntut Modal dan Pelayanan Terpadu Satu Pintu
Copyright ( 2019 , Publik (Jurnal Ilmu Administrasi), ISSN: 2301-573X (Print), ISSN: 2581-2084 (Online) untuk menggunakan solusi kreatif dengan memaksimalkan sumber daya yang dimilikinya dan hal tersebut dilakukan melalui inovasi. Pada sektor swasta, inovasi sudah menjadi sebuah kebutuhan sebagai cara untuk bertahan hidup dengan mempertahankan loyalitas konsumen dan memenangkan persaingan pasar atas kompetitornya. Saat ini, sektor publik tanpa terkecuali juga harus mampu berinovasi demi menjawab tuntutan publik yang hadir sebagai konsekuensi atas pekembangan tekhnologi dan perkembangan lingkungan sosial masyarakat yang semakin kompleks.

Inovasi yang diterapkan pemerintah telah memberikan hasil positif untuk keuntungan sektor publik yaitu, Pertama, mendukung memaksimalkan utilitas sumber daya dan kapasitas untuk pengembangan nilai publik untuk melakukan budaya keterbukaan dan partisipasi dalam pemerintahan. Kedua, inovasi memperkuat kepercayaan masyarakat dan legitimasi pemerintah. Ketiga, inovasi dapat meningkatkan kepercayaan diri aparat dan dapat menjadi kekuatan pendorong bagi perbaikan diri. Keempat, inovasi memunculkan efek domino yang dapat membuka inovasi lain di tempat yang berbeda. Kelima, menghasilkan peluang untuk inovasi yang berkelanjutan, yang mendukung untuk perubahan positif terhadap lingkungan. (Alberti dan Bertucci, 2006).

Evaluasi penyelenggaraan pelayanan PTSP DKI Jakarta yang dilakukan oleh Ombudsman di tahun 2015 masih menemukan berbagai kekurangan yang terjadi antara lain lamanya proses antrian pengurusan perizinan, keluhan mengenai prosedur yang berbelit dan lamanya proses penyelesaian izin. Selain itu, adanya perbedaan tingkatan kewenangan dalam pemrosesan izin pada Dinas Penanaman Modal dan Pelayanan Terpadu Satu Pintu 
(DPMPTSP) DKI Jakarta yang diatur dalam Peraturan Gubernur DKI Jakarta Nomor 411 Tahun 2015 tentang Pembagian Kewenangan Penandatanganan Naskah Dinas dan Dokumen Perizinan dan Non Perizinan pada Badan Pelayanan Terpadu Satu Pintu juga menyebabkan adanya keluhan waktu dan biaya dari para pemohon perizinan (Firmansyah, 2018; Subowo, 2019).

Salah satu upaya DPMPTSP untuk meningkatkan kualitas pelayanan sekaligus mengatasi keluhan masyarakat tersebut adalah melalui pembentukan Layanan Antar Jemput Izin Bermotor (AJIB). AJIB merupakan pionir dan menjadi salah satu contoh best practice dalam layanan jemput berkas di Indonesia, dimana petugas melakukan penjemputan, melakukan verifikasi persyaratan langsung di lokasi pemohon berada, kemudian mengeskalasikan berkas tersebut sesuai dengan lokasi kewenangan unit layanan PTSP, dan mengantarkan kembali perizinan yang telah selesai diproses di Unit Pelayanan PTSP ke lokasi pemohon tanpa dikenakan biaya (gratis). Sejak diluncurkan di Bulan Januari 2016, hingga Desember 2018 AJIB telah melayani total 411.583 permohonan. Terdapat dua cara untuk mengakses layanan AJIB, yaitu secara online dan offline. Online adalah ketika masyarakat secara langsung atau dengan inisiatifnya sendiri mengakses layanan AJIB melalui call center ataupun melalui aplikasi pada ponsel pintar. Sedangkan cara offline adalah ketika adalah ketika unit pelayanan PTSP menjadi inisiator dalam penggunaan layanan AJIB misalnya untuk menyerahkan hasil jadi perizinan kepada pemohon. Di tahun 2016 sampai dengan 2018 terdapat 38.893 permohonan pengguna AJIB yang mengakses layanan AJIB secara online atau sekitar $9.7 \%$ inisiator pengguna AJIB yang merupakan masyarakat pemohon langsung baik menggunakan aplikasi AJIB di playstore ataupun melalui call center. Sedangkan sebanyak 360.564 permohonan atau sekitar $90.3 \%$ inisiator layanan AJIB adalah kantor PTSP, dimana pemohon tetap datang ke kantor PTSP untuk mengurus perizinannya lalu setelah berkas perizinan selesai diproses, baru perizinan tersebut diantarkan oleh petugas AJIB kepada Pemohon.

Salah satu tujuan dari hadirnya layanan AJIB adalah memberikan kemudahan dan mengurangi beban biaya yang dikeluarkan oleh masyarakat atau pelaku usaha dalam pengurusan perizinan, sekaligus memberantas praktek percaloan yang memberikan stigma negatif dalam pelayanan publik. Akan tetapi, dari data diatas, terlihat rendahnya akses layanan AJIB yang dilakukan oleh pemohon secara langsung dan hal ini merupakan indikasi yang kurang baik atas adopsi inovasi AJIB. Adopsi inovasi adalah sebuah pengambilan keputusan untuk melanjutkan pengimplementasian inovasi baik secara keseluruhan maupun sebagian dimana melalui sebuah proses yang kompleks, dan dengan memahami hal ini akan memberikan pemahaman guna pengembangan strategi untuk meningkatkan perbaikan dari implementasi inovasi (Fixen, 2005). Dengan kata lain, keberhasilan adopsi inovasi menentukan keberhasilan serta menentukan keberlangsungan hidup inovasi itu sendiri. Hal inilah yang menarik peneliti untuk menganalisis adopsi inovasi layanan antar jemput izin bermotor (AJIB). Tujuan dari penelitian ini adalah untuk mengetahui faktor-faktor apa saja yang mempengaruhi adopsi inovasi layanan AJIB yang disediakan oleh DPMPTSP Provinsi DKI Jakarta yang selanjutnya akan digunakan sebagai acuan untuk perkembangan dan 
evaluasi pelayanan publik yang diselenggarakan oleh DPMPTSP DKI Jakarta.

\section{METODE PENELITIAN}

Peneliti menggunakan metode penelitian deskriptif kualitatif dengan pendekatan post postivisme. Pendekatan post positivisme tidak dimaksudkan untuk mempertanyakan kesalahan atau kebenaran dari sebuah teori, melainkan teori digunakan sebagai instrument prediksi dengan tetap mencari fakta dan realitas yang objektif. Pengumpulan data dalam penelitian ini diperoleh melalui wawancara mendalam, observasi lapangan serta penalaahan atas dokumentasi berupa dokumen publik seperti koran, laporan, peraturan maupun makalah serta dokumen berbentuk audio visual yang terkait dengan layanan AJIB DPMPTSP Provinsi DKI Jakarta. Pisau analisis yang digunakan dalam penelitian ini adalah konstruksi model adopsi inovasi yang dikemukakan oleh Wisdom, et al., (2013).

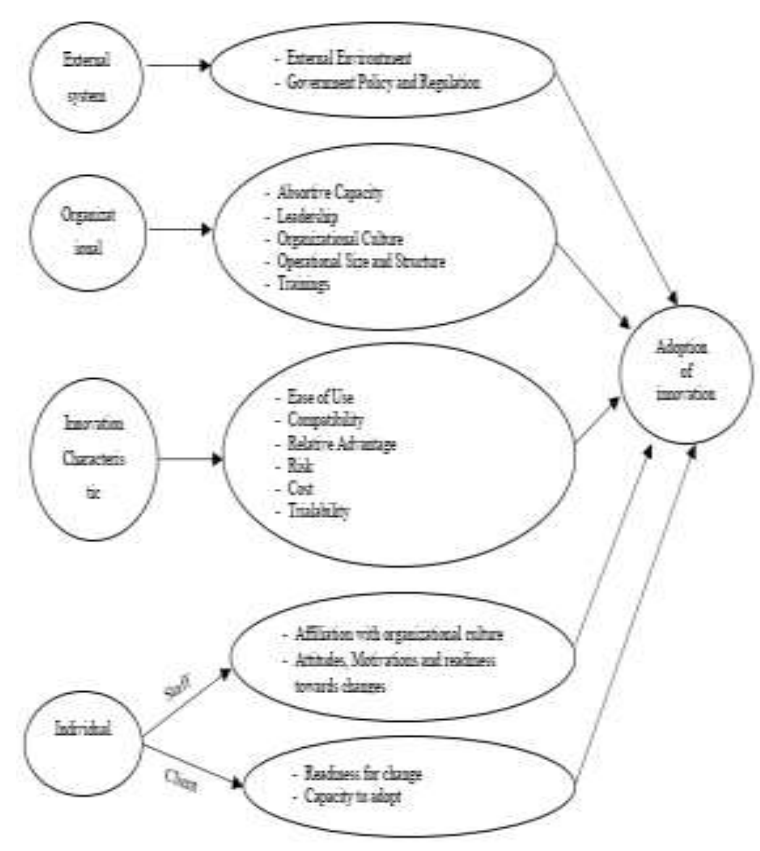

Gambar 1. Model Adopsi Inovasi Wisdom, et al (2013)

\section{HASIL DAN PEMBAHASAN}

Faktor - faktor yang mempengaruhi adopsi inovasi layanan Antar Jemput Izin Bermotor pada Dinas Penanaman Modal dan Pelayanan Terpadu Satu Pintu Provinsi DKI Jakarta

\section{a. Sistem Eksternal}

Kebijakan negara dan regulasi dapat mempengaruhi adopsi inovasi (Chor, et al., (2017). Bentuk dukungan Pemerintah atas inovasi sektor publik tertuang dalam beberapa regulasi antara lain dalam UU No. 23 Tahun 2014 tentang Pemerintahan Daerah pasal 356 sampai dengan 390 dimana pemerintah pusat mengakomodir pemerintah daerah untuk melakukan inovasi demi peningkatan kualitas pelayanan publik. Dilanjutkan dengan dikeluarkannya Peraturan Pemerintah No 38 Tahun 2017 tentang inovasi daerah sebagai petunjuk pelaksanaan tekhnis, menunjukkan dukungan pemerintah pusat dalam penciptaan inovasi yang bertujuan pada peningkatan kinerja penyelenggaraan pemerintahan daerah. Selain itu juga dikeluarkan Peraturan Menteri Pemberdayaan Aparatur Negara dan Reformasi Birokrasi (PermenPANRB) No. 19 Tahun 2016 tentang pedoman kompetisi Inovasi Pelayanan Publik yang mendorong gerakan One Agency, One Innovation, dimana setiap Kementerian/ Lembaga dan Pemerintah Daerah (Provinsi, Kabupaten, Kota) wajib menciptakan minimal satu buah inovasi setiap tahunnya.

Peraturan daerah No. 12 Tahun 2013 tentang Penyelenggaraan Pelayanan Terpadu Satu Pintu serta Peraturan Gubernur No.47 Tahun 2017 tentang Petunjuk Penyelenggaraan Pelayanan Terpadu Satu Pintu menjadi dasar regulasi penyelenggaraan pelayanan publik di Provinsi DKI Jakarta. Akan tetapi, hingga saat ini masih belum terdapat regulasi spesifik yang menjadi dasar Copyright @ 2019, Publik (Jurnal Ilmu Administrasi), ISSN: 2301-573X (Print), ISSN: 2581-2084 (Online) 
penyelenggaraan layanan AJIB

DPMPTSP. Hal ini tentu berdampak pada proses penyelenggaraan layanan AJIB. Disampaikan oleh Aarons, et al. (2011) Kebijakan dan regulasi berasosiasi positif dengan adopsi, termasuk berlakunya kebijakan, perundang-undangan atau peraturan khusus tentang adopsi inovasi. Regulasi menjadi jaminan bagi keberlangsungan serta keberlanjutan sebuah inovasi dalam sebuah organisasi. Dengan adanya regulasi yang menjadi payung hukum, maka akan memberikan keleluasaan bagi organisasi untuk mengambil langkah dalam upaya meningkatkan kualitas sebuah inovasi, termasuk dukungan secara finansial. Selain dukungan regulasi, faktor lingkungan eksternal juga mempengaruhi proses adopsi inovasi (Wisdom, et al., 2013).

Saat ini Indonesia sudah memasuki era revolusi industri 4.0 yang berdampak pada penyelenggaraan pelayanan perizinan di DPMPTSP. Dari total 269 jenis perizinan, sebanyak 238 diantaranya dilakukan secara online dan tidak lagi memerlukan berkas secara fisik, terlebih lagi beberapa jenis perizinan online sudah menggunakan tanda tangan elektronik dimana pemohon dapat mencetak langsung hasil jadi perizinan dari perangkat elektonik milik pemohon sendiri. Hal ini tentu juga berpengaruh terhadap penggunaan layanan AJIB, dimana tugas AJIB adalah untuk menerima dan mengantarkan berkas fisik permohonan dari masyarakat kepada unit pelayanan PTSP dan menyerahkan hasil jadi perizinan kembali kepada pemohon. Hal ini harus menjadi perhatian bagi DPMPTSP khususnya divisi AJIB untuk terus berinovasi dalam menghadapi tantangan revolusi industry 4.0 tersebut dan melihat peluang yang muncul agar
AJIB bisa tetap berdayaguna dengan maksimal.

\section{B. Organisasi}

Dukungan pemimpin, nilai, norma dan budaya organisasi berkorelasi secara positif terhadap adopsi inovasi. Kepemimpinan yang berorientasi pada peningkatan kualitas diasosiasikan dengan kecepatan dan intensitas adopsi inovasi (Ravichandra, 2000; Damanpour, 2006). Proses inovasi membutuhkan pemimpin yang mampu menyadari banyak hal tentang pentingnya inovasi, mampu mengarahkan dan menjadi model pribadi yang dapat memberikan contoh yang tepat dalam mendukung inovasi (Sihombing, 2016). Kepala Dinas PMPTSP Provinsi DKI Jakarta memberikan dukungan atas munculnya inovasi AJIB ini dengan penyediaan sarana dan prasarana serta anggaran guna operasional AJIB, selain itu juga dorongan untuk mensosialisasikan layanan AJIB ini melalui seluruh lini unit pelayanan DPMPTSP di DKI Jakarta. Pertemuan internal dilakukan secara berkala untuk membahas isu isu serta upaya perbaikan layanan, termasuk di dalamnya layanan AJIB.

Budaya organisasi yang konstruktif mendorong peningkatan kualitas inovasi. Profil budaya organisasi yang baik dimana tingkat kemahiran staf tinggi dan memliki tingkat rigiditas/ kekakuan yang rendah dan tingkat resistensi yang rendah terhadap perubahan berkorelasi positif terhadap adopsi inovasi, peningkatan kualitas layanan serta kepuasan (Glison et al., 2008). Di DPMPTSP Prov DKI Jakarta, setiap anggota organisasi dapat menyampaikan masukan dan saran atas perbaikan organisasi. Saluran penyampaian aspirasi dibuka seluas luasnya melalui berbagai cara antara lain melalui pertemuan rutin bahkan melalui media lain 
seperti email ataupun whatsaap group. Setiap anggota organisasi terus didorong berperan aktif demi kemajuan organisasi melalui nilai organisasi yaitu SETIA (solusi, empati, tegas, inovasi, andal). Petugas AJIB sudah memiliki pengetahuan dan ketrampilan dasar yang dibutuhkan untuk menjalankan peranannya, akan tetapi dari hasil penelitian, diketahui bahwa masih terdapat ketimpangan kemampuan terutama dalam analisa persyaratan antar petugas AJIB. Pelatihan yang diberikan oleh DPMPTSP dirasakan masih harus ditingkatkan terutama terkait dengan hal hal tekhnis administrasi mengingat bahwa petugas AJIB merupakan garda terdepan pelayanan publik DKI Jakarta.

\section{Inovasi}

Karakteristik inovasi mempengaruhi adopsi inovasi. Inovasi yang mudah digunakan, lebih baik dari praktek yang berjalan sebelumnya, dapat diamati, hemat biaya, berbasis bukti, sejalan dengan nilai dan norma, serta beresiko rendah akan lebih mudah diadopsi (Wisdom, et al., 2013). AJIB merupakan pionir dan menjadi salah satu contoh best practice dalam layanan jemput berkas di Indonesia, dimana petugas melakukan penjemputan, melakukan verifikasi persyaratan langsung di lokasi pemohon berada, kemudian mengeskalasikan berkas tersebut sesuai dengan lokasi kewenangan unit layanan PTSP baik yang berada di Dinas, Kota, Kecamatan maupun Kelurahan, dan mengantarkan kembali perizinan yang telah selesai diproses di Unit Pelayanan PTSP ke lokasi pemohon dan tidak dikenakan biaya (gratis). Sebelum adanya layanan AJIB, masyarakat harus meluangkan waktu, tenaga dan biaya untuk menuju lokasi kantor DPMPTSP, belum lagi jika ternyata masih ada kekurangan yang harus dilengkapi oleh pemohon, maka yang bersangkutan harus berulang Copyright (C 2019, Publik (Jurnal Ilmu Administrasi), ISSN: 2301-573X (Print), ISSN: 2581-2084 (Online) datang ke kantor DPMPTSP hingga perizinannya selesai diproses dan hal ini menjadi celah bagi para calo perizinan. Akan tetapi, sejak hadirnya inovasi AJIB, maka masyarakat tidak perlu lagi datang ke lokasi kantor DPMPTSP untuk mengurus perizinan. Pemohon cukup mengakses layanan AJIB melalui call center 1500164 ataupun melalui aplikasi AJIB yang tersedia pada play store dan petugas AJIB akan datang untuk menjemput berkas perizinan. Inovasi AJIB membawa dampak positif yang bisa langsung dirasakan oleh masyarakat dalam hal efisiensi waktu, biaya, tenaga serta informasi atas persyaratan dan retribusi perizinan yang lebih akurat.

Akan tetapi, dari hasil penelitian, diperoleh temuan bahwa muncul keluhan atas sulitnya akses AJIB melalui call center ataupun melalui aplikasi AJIB di play store. Aplikasi AJIB di play store seringkali mengalami gangguan/ error yang mengakibatkan tidak dapat diakses nya layanan tersebut. Call center 1500164 seringkali dalam keadaan sibuk sehingga sulit untuk dihubungi. Hal ini menjadi pertimbangan bagi pemohon untuk tidak menggunakan layanan AJIB. Kendala pada Aplikasi AJIB diketahui disebabkan oleh adanya proses migrasi server internal. Saat ini sedang dilakukan upaya penyempurnaan pada aplikasi guna mengatasi kendala tersebut. Jumlah call center pada DPMPTSP hanya 30 orang yang bertugas selain untuk menerima pemesanan AJIB tetapi juga untuk memberikan informasi dan juga menerima layanan complain atau keluhan dari pemohon terkait layanan perizinan dan non perizinan dari DPMPTSP, sehingga tidak mencukupi untuk penerimaan layanan. Berdasarkan data laporan tahunan DPMPTSP tahun 2018 jumlah layanan call center sepanjang 2018 sebanyak 159.678, 
dimana sebanyak 16.718 diantaranya adalah untuk layanan pemesanan AJIB.

Selain kendala atas akses AJIB, dari hasil penelitian, diketahui masih terdapat masyarakat atau pelaku usaha yang belum mengetahui mengenai adanya layanan antar jemput perizinan ini. Oleh karena itu, diperlukan upaya yang lebih baik lagi dari DPMPTSP untuk mensosialisasikan layanan AJIB.

\section{Individual}

Dimensi individual menurut Wisdom berpengaruh terhadap adopsi inovasi. Individu terbagi atas staff pelaksana dan individu pengguna inovasi. Karakteristik staff untuk mengadopsi inovasi terkait dengan kesiapan staff terhadap inovasi, afiliasi dirinya dengan budaya organisasi, sikap, motivasi dan serta ketaatan terhadap inovasi. Terkait dengan kesiapan staff terhadap inovasi, petugas ajib direkrut dengan kualifikasi pendidikan minimal S1 serta melalui serangkaian test seperti psikotest dan tes kemampuan dasar. Sebelum menjalankan tugasnya sebagai staff AJIB, mereka diberikan pelatihan dasar tentang persyaratan perizinan. Petugas AJIB harus mampu melakukan pengecekan dasar dokumen perizinan di PTSP yang berjumlah 267 perizinan, oleh karena itu untuk memudahkan maka para petugas AJIB diberikan akses atas web PTSP yang berisikan seluruh persyaratan perizinan. Terkait dengan budaya dan nilai organisasi, dari wawancara yang dilakukan kepada para petugas AJIB mereka menyampaikan bahwa penekanan nilai nilai SETIA (solusi, empati, tegas, inovasi, andal) selalu ditekankan kepada para petugas, selain itu nilai integritas juga selalu dijunjung tinggi oleh para petugas. Dari hasil wawancara, para petugas AJIB merasa bangga atas hasil kerja mereka, karena mereka merasa bahwa pekerjaan mereka memberikan kemudahan kepada masyarakat dan membawa perubahan pelayanan publik kearah lebih baik. Penanaman nilai SETIA selalu ditanamkan kepada seluruh anggota organisasi, selain tercetak dalam simbol organisasi seperti pin dan seragam, nilai setia selalu disampaikan dalam setiap pertemuan organisasi. Pengawasan internal juga dilakukan terhadap para petugas seperti mystery shopper serta survei melalui telepon dari internal PTSP kepada beberapa pengguna jasa AJIB.

Menurut Chor et al., (2017) Perspektif pengguna inovasi (klien) dapat dilihat melalui motivasi untuk menggunakan inovasi, kemampuan menggunakan inovasi serta dukungan dari klien untuk perubahan/ perbaikan. Dari hasil wawancara yang dilakukan kepada klien pengguna jasa AJIB, mereka menyatakan bahwa AJIB merupakan inovasi dari DPMPTSP yang sangat bermanfaat terutama memberikan kemudahan dalam hal waktu, tenaga dan biaya dalam pengurusan perizinan. Salah satu klien pengguna menyatakan bahwa sebelum adanya AJIB, perusahaan harus mengeluarkan nominal hingga jutaan rupiah untuk merekrut pihak lain (calo) untuk pengurusan perizinan karena keterbatasan waktu dan tenaga untuk mengurus perizinan. Akan tetapi sejak mengetahui adanya AJIB, maka tidak perlu lagi mengeluarkan biaya untuk pengurusan perizinan, karena petugas AJIB yang langsung datang ke kantor untuk melakukan pemeriksaan dasar dan penjemputan dokumen perizinan untuk diserahkan kepada Kantor DPMPTSP, setelah izin selesai, juga diantarkan kembali ke kantor pemohon. AJIB yang dapat diakses melalui call center dan aplikasi pada playstore juga diapresiasi oleh klien pengguna, akan tetapi diperoleh 
temuan bahwa klien mengalami kesulitan dalam hal akses melalui call center dan aplikasi. Call center seringkali sibuk dan aplikasi AJIB seringkali mengalami kendala tekhnis, sehingga klien akhirnya datang langsung ke kantor DPMPTSP untuk mengurus perizinannya, dan meminta setelah perizinan selesai diproses maka perizinan tersebut diantarkan ke kantor klien oleh petugas AJIB. dukungan untuk perbaikan layanan AJIB dilakukan oleh klien dengan cara menyampaikan saran dan masukan kepada DPMPTSP melalui call center ataupun ketika datang untuk mengurus perizinan, karena klien merasakan manfaat atas hadirnya layanan AJIB.

\section{PENUTUP}

\section{Kesimpulan}

Setelah dilakukan penelitian terhadap adopsi inovasi Antar Jemput Izin Bermotor pada Dinas Penanaman Modal dan Pelayanan Terpadu Satu Pintu Provinsi DKI Jakarta diketahui proses adopsi inovasi terhadap layanan AJIB belum berjalan dengan maksimal yang terlihat dari rendahnya akses online dari masyarakat atas layanan ini. Terdapat beberapa dimensi yang perlu diperbaiki agar adopsi inovasi AJIB dapat berjalan dengan maksimal seperti pada dimensi sistem eksternal, perlu dibuatnya regulasi yang secara khusus memayungi hadirnya layanan Antar Jemput Izin Bermotor. Keluhan atas sulitnya akses terhadap layanan AJIB terutama akses secara online baik melalui call center ataupun melalui aplikasi AJIB pada playstore menjadi pertimbangan bagi pemohon untuk tidak menggunakan layanan AJIB. Selain itu, dari wawancara yang dilakukan kepada para narasumber, diperoleh temuan bahwa sosialisasi terhadap layanan AJIB ini masih kurang berjalan maksimal, karena masih banyak pemohon perizinan yang masih Copyright (C) 2019, Publik (Jurnal Ilmu Administrasi), ISSN: 2301-573X (Print), ISSN: 2581-2084 (Online) belum mengetahui adanya layanan AJIB ini.

Dari hasil temuan penelitian, diharapkan dapat membantu untuk penyusunan strategi guna meningkatkan adopsi atas layanan AJIB, sehingga dapat berjalan lebih maksimal dan mencapai tujuan dari penciptaan inovasi yaitu meningkatkan kualitas pelayanan publik sekaligus menghapuskan praktek percaloan perizinan khususnya pada Dinas Penanaman Modal dan Pelayanan Terpadu Satu Pintu Provinsi DKI Jakarta.

\section{Saran}

Penelitian ini mencoba untuk melihat inovasi layanan Antar Jemput Izin Bermotor pada Dinas Penanaman Modal dan Pelayanan Terpadu Satu Pintu dari sisi adopsi inovasi. Untuk penelitian selanjutnya diharapkan yang diteliti tidak hanya terbatas pada faktor adopsi inovasinya saja tapi melihat sampai kepada proses difusi inovasi dari layanan AJIB pada Dinas Penanaman Modal dan Pelayanan Terpadu Satu Pintu Provinsi DKI Jakarta.

\section{DAFTAR PUSTAKA}

Aarons, G. A., Hurlburt, M., \& Horwitz, S. M. (2010). Advancing a Conceptual Model of Evidence-Based Practice Implementation in Public Service Sectors. Administration and Policy in Mental Health and Mental Health Services Research, Vol. 38, No. 1, 423

Alberti,Adriana \& Guido Bertucci. (2006).

Replicating Inovations in Governance : An Overview. USA: United Nations Publikations

Chor,KH, Wisdom JP, Olin SC, Hoagwood KE, Horwitz SM.. (2015). Measures for Predictors of Innovation Adoption: Adm Policy Ment Health, Vol. 42(5), 545-573 
Damanpour F, Schneider M. (2009). Characteristics of innovation and innovation adoption in public organizations: Assessing the role of managers. Journal of Public Administration Research and Theory. Volume 19(3):495-522

De Vries, Hanna and Tummers, Lars and Bekkers, V.J.J.M. (2018). The Diffusion and Adoption of Public Sector Innovations: A MetaSynthesis of the Literature. Perspectives on Public Management and Governance, Forthcoming. Vol 9, 1- 44

DL Fixsen, N. S. (2005). Implementation Research: A synthesis of the literature. Tampa: University of South Florida .

Firmansyah, Iqbal \& Retnowati WD Tuti. (2017). Innovation Of Shutte Service of Motor License in DKI Jakarta. Proceeding of The First International Conference on Social Sciences. Jakarta: University of Muhamadiyah

Sihombing, Tunggul. (2016). Publik Sektor Innovation and Reform Towards Good Local Governance. Global Journal of Politics and Law Research, Vol. 4, No.1, 64-72

Subowo, et,al. (2019). Institutional Optimization Strategy of Capital Investment Agency and One Stop Integrated Services. Jurnal Bina Praja. Vol 11, No.2, 237-248

Wisdom JP, Chor KHB, Hoagwood KE, Horwitz SM. (2013). Innovation adoption: A review of theories and constructs. Administration and Policy in Mental Health and Mental Health Services Research. Vol.41(4), 480-502. 